\title{
REFERENCES
}

1. C. G. Rogers, Can. J. Biochem. 46, 331 (1968).

2. H. N. GuTtMan and W. FRIEDman, Trans. N.Y. Acad. Sci. 26, 75 (1963).

3. J. D. JudAH and K. AHMED, Biochim. biophys. Acta 71, 34 (1963).

4. L. Roizin, M. K. Kaufman, B. Ballard, R. Sabin and W. Horwitz, Psychopharmac. Serv. Cent. Bull. 2, 81 (1962).

5. K. W. A. WirTZ and D. B. Zilversmit, J. biol. Chem. 243, 3596 (1962).

6. E. G. Bligh and W. J. DYer, Can. J. Biochem. Physiol. 37, 911 (1959).

7. J. BeARe-Rogers, Can. J. Biochem. 47, 257 (1969).

8. J. J. Wren and A. D. SzCZEPANOWSKA, J. Chromat. 14, 405 (1964).

9. G. R. BARTLETT, J. biol. Chem. 234, 466 (1959).

10. F. PArker and N. F. Peterson, J. Lipid Res. 6, 455 (1965).

11. W. P. Burkard, K. F. GeY and A. Pletscher, Nature, Lond. 213, 732 (1967).

12. M. A. Williams, K. T. TAmai and D. J. McIntosh, Biochim. biophys. Acta 137, 186 (1967).

13. M. A. Williams, D. J. McIntosh, K. T. Tamai and I. Hincenbergs, Proc. Soc. exp. Biol. Med. $127,36(1968)$.

14. J. H. Veerkamp, J. Mulder and L. L. M. Van Deenen, Biochim. biophys. Acta 57, 299 (1962).

15. A. W. Cuthbert, Pharmac. Rev. 10, 59 (1967).

Biochemical Pharmacology, Vol. 20, pp. 2522-2527. Pergamon Press, 1971. Printed in Great Britain

\section{Effects of the carcinogen methylazoxymethanol acetate on protein synthesis and drug metabolism in rat livers*}

(Received 2 November 1970; accepted 12 February 1971)

MeThylazoxymethanol (MAM) acetate is a synthetic derivative of cycasin, a carcinogen derived from plants of the cycad family. ${ }^{1,2}$ Cycasin, MAM and MAM acetate have been shown to induce tumors primarily in the liver, kidney, and intestine of rats after a single or small number of doses. ${ }^{3-5}$ Zedeck et al. ${ }^{5}$ reported that there was a rapid inhibition of DNA, RNA and protein synthesis which occurred in liver within $3 \mathrm{hr}$ after giving MAM acetate. In addition, nucleolar damage was evident within $1 \mathrm{hr}$ and preceded inhibition of nuclear RNA synthesis. Disaggregation of polysomes and depletion of rough endoplasmic reticulum have also been observed to occur in rat liver within a few hours after giving MAM.6.7 The present study was undertaken to determine the effects of MAM acetate on various functions of the microsomal fraction of rat liver in order to further elucidate biochemical actions of the carcinogen which might be involved in the initial events leading to formation of neoplasia. The effects of MAM acetate were compared to those of dimethylnitrosamine (DMN), a chemically similar carcinogen. The agents were found to have very similar effects on protein synthesis and drug-metabolizing enzymes.

MAM acetate was purchased from Mann Research Laboratories, Inc., dimethylnitrosamine from Eastman Kodak Co., and L-leucine-4,5- ${ }^{3} \mathrm{H}(38.5 \mathrm{c} / \mathrm{m}$-mole) from New England Nuclear Corp. Male Sprague-Dawley rats $(60-70 \mathrm{~g})$ were obtained from Spartan Farms, Lansing, Mich. and allowed food and water ad lib.

All injection solutions were prepared in $0.9 \% \mathrm{NaCl}$. Injections were given intraperitoneally in a volume of $0.2 \mathrm{ml}$ with the exception of pulse-doses of $\mathrm{L}$-leucine- ${ }^{3} \mathrm{H}$, which were given by tail vein injection. Control animals were injected with saline solution. All animals were sacrificed by decapitation. For the drug metabolism studies, the animals were sacrificed between 8 and 9 a.m. In the case of polysome preparations, all animals were sacrificed between 1 and 2 p.m. to avoid possible diurnal variations in polysome patterns. ${ }^{8}$

* Address reprint requests to: Dr. R. W. Ruddon, Pharmacology Section, Department of Oral Biology, University of Michigan Dental School, Ann Arbor, Michigan 48104, U.S.A. 
To prepare microsomes animals were decapitated, and their livers immediately removed, rinsed in iced $0.25 \mathrm{M}$ sucrose- $3 \mathrm{mM} \mathrm{MgCl}$, placed in 3 vol. of sucrose-- $\mathrm{MgCl}_{2}$ solution in a Dounce tube, and homogenized. The homogenate was centrifuged at $12,500 \mathrm{~g}$ at $0^{\circ}$ for $20 \mathrm{~min}$. The postmitochondrial supernatant was then centrifuged at $105,000 \mathrm{~g}$ for $60 \mathrm{~min}$ at $0^{\circ}$ in a Spinco $50 \mathrm{Ti}$ rotor. The microsomal pellets were washed by resuspension in sucrose- $\mathrm{MgCl}_{2}$ solution and recentrifugation at 105,000 $g$ for $60 \mathrm{~min}$. Metabolism of ethylmorphine and norcodeine was determined in microsomes by a modification of the method of George and Tephly. ${ }^{9}$ Reaction mixtures $(5 \mathrm{ml})$ contained $0.5 \mathrm{~m}$-mole of phosphate buffer (pH 7.4), $0.3 \mathrm{~m}$-mole of $\mathrm{KCl}, 2.25 \mu$ moles of $\mathrm{MgCl}_{2}, 38 \mu$ moles of semicarbazide$\mathrm{HCl}, 6 \mu$ moles of glucose 6-phosphate, $2.2 \mu$ moles NADP, $4 \mu$ moles of ethylmorphine or norcodeine, 2 units of glucose 6-phosphate dehydrogenase, and 8-10 mg of microsomal protein. The samples were incubated for $10 \mathrm{~min}$ at $37^{\circ}$, and the reactions stopped by the addition of $0.4 \mathrm{ml}$ of $70 \%$ perchloric acid. Metabolism was estimated by the production of formaldehyde according to the procedure of Nash. ${ }^{10}$ Protein determinations were done by the method of Lowry et al. ${ }^{11}$

Polyribosomes were prepared by the procedure of Blobel and Potter ${ }^{12}$ and analyzed on 10-30 per cent linear sucrose gradients. The area of monomer and dimer peaks and the total area of the polysome patterns were measured by a compensating polar planimeter. The percentage of intact polysomes was calculated as the per cent of the total area composed of the monomer plus dimer peaks subtracted from 100 per cent.

Incorporation of ${ }^{3} \mathrm{H}$-leucine $(50 \mu \mathrm{c})$ into microsomal protein was determined after a $10 \mathrm{~min}$ pulsedose given intravenously. Aliquots $(1 \mathrm{ml})$ of microsomal suspension containing approximately $2 \mathrm{mg}$ of microsomal protein were added to $10 \mathrm{ml}$ of Scintisol-toluene counting solution ( $2 \mathrm{ml}$ of Scintisol per $10 \mathrm{ml}$ of toluene scintillator solution [3 g PPO, $100 \mathrm{mg}$ POPOP/l. toluene]) and counted on a Packard Tri-carb liquid scintillation spectrometer.

Incorporation of ${ }^{3} \mathrm{H}$-leucine into microsomal protein in vivo was measured at various times after a $20 \mathrm{mg} / \mathrm{kg}$ dose of MAM acetate (Fig. 1). Protein synthesis was inhibited 50 per cent below control levels $1 \mathrm{hr}$ after treatment, and maximal inhibition ( 70 per cent) was observed at $2 \mathrm{hr}$. Incorporation of labeled amino acid returned to control levels by $24 \mathrm{hr}$ after a single injection. The inhibition of polypeptide formation cannot be explained on the basis of an inhibitory effect of MAM acetate on the equilibration of labeled leucine with the amino acid pool in liver. The specific activities of the acid soluble pools from liver homogenates in two separate experiments were 1572 and 2293 counts/min/ $A_{280}$ for the controls, while the corresponding values for animals treated with $20 \mathrm{mg} / \mathrm{kg}$ of MAM acetate were 1789 and 3204 counts $/ \mathrm{min} / \mathbf{A}_{280}$ respectively. This pattern of inhibition of protein synthesis was similar to that reported by Zedeck et al..$^{5}$ with the exception that we observed a peak inhibitory response at $2 \mathrm{hr}$ and a beginning of return toward control thereafter. In addition, in the

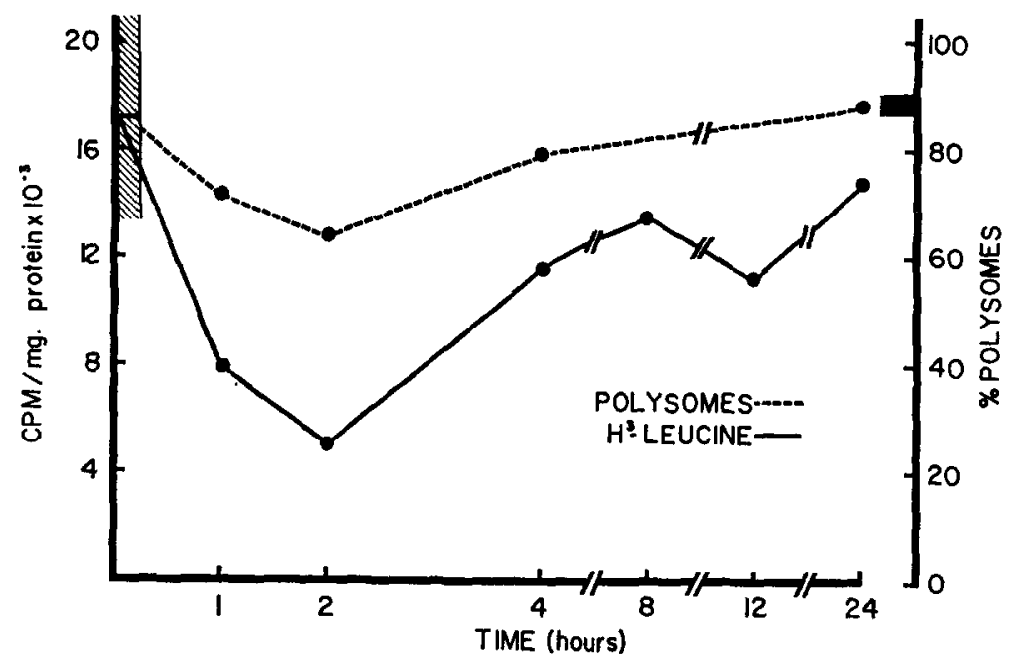

FIG. 1. Effect of MAM acetate $(20 \mathrm{mg} / \mathrm{kg})$ on hepatic protein synthesis and polysome aggregation. Incorporation of leucine $-4,5-{ }^{3} \mathrm{H}$ into microsomal protein and polysome aggregation were determined as described in the text. For each time period studied the livers of two rats were pooled for both control and MAM acetate-treated animals. The range in incorporation of labeled leucine into microsomal protein (striped bar) was based on data from 12 control animals. The range of "intact polysomes" (minus monomer and dimer area) was based on determinations from eight animals (solid bar). 
studies reported herein a relationship was established between decreased polypeptide formation and polysome disaggregation (Fig. 1). The polysome patterns 2 and $24 \mathrm{hr}$ after MAM acetate are shown in Figs. 2 and 3.

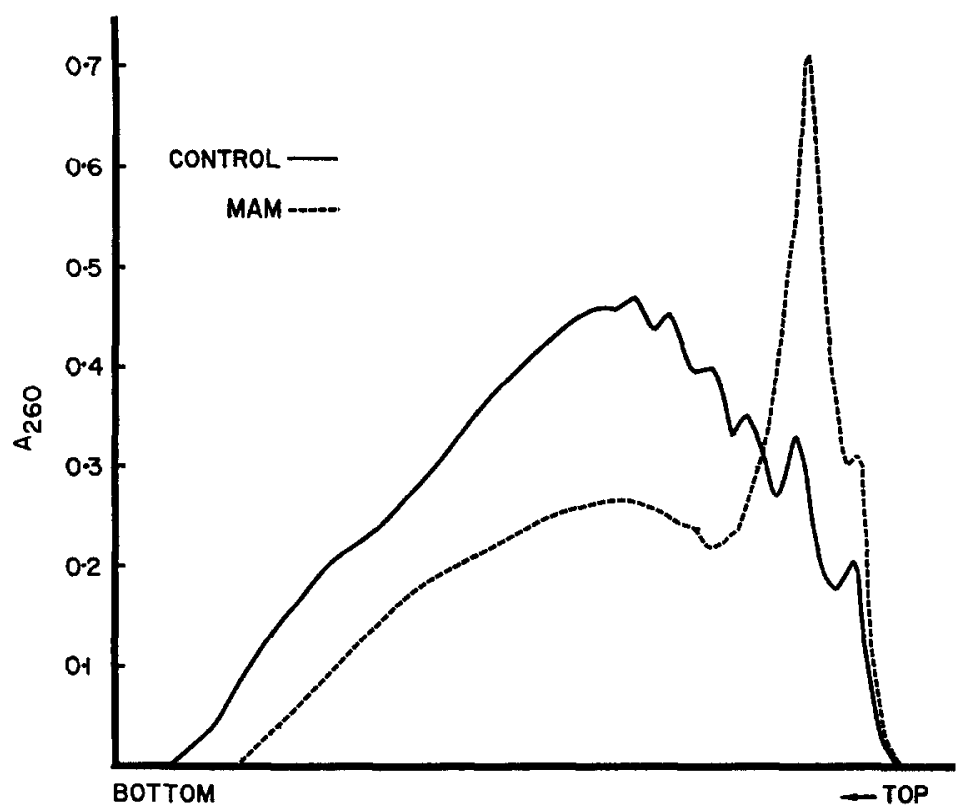

Fig. 2. Polysome patterns at $2 \mathrm{hr}$ after MAM acetate $(20 \mathrm{mg} / \mathrm{kg})$.

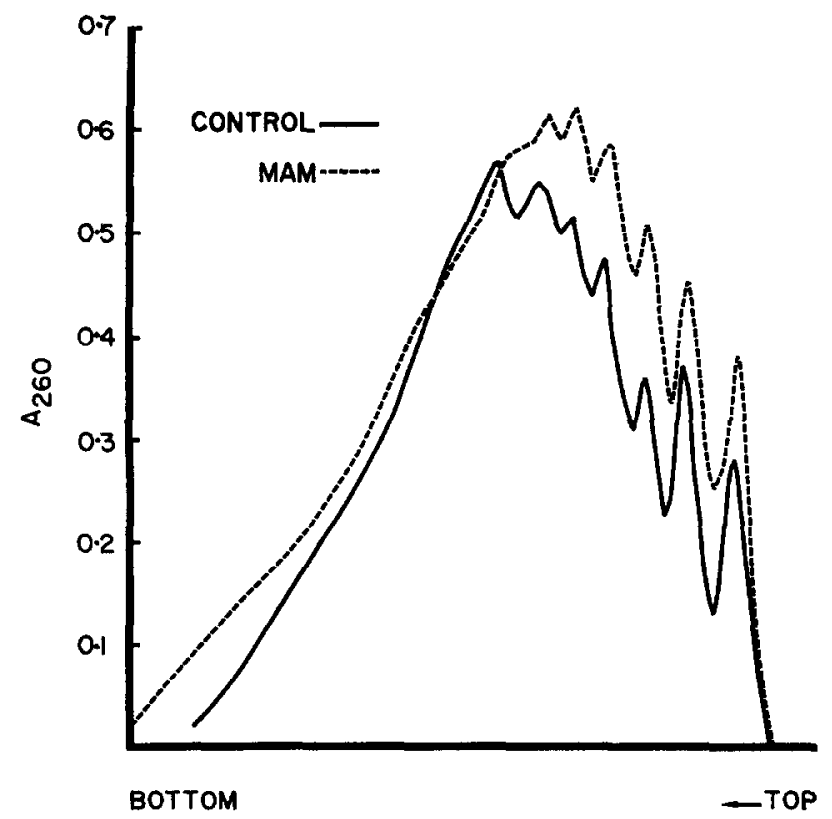

Fig. 3. Polysome patterns at $24 \mathrm{hr}$ after MAM acetate $(20 \mathrm{mg} / \mathrm{kg})$. 
The effects of DMN on hepatic protein synthesis in vivo and polysome aggregation were very similar to those of MAM acetate. ${ }^{*}$ These latter findings are in agreement with those of Villa-Trevino. ${ }^{13}$ Inhibition of incorporation of nucleotide precursors into nuclear RNA does not precede protein synthesis inhibition after giving MAM or DMN, suggesting that decreased protein synthesis is not due to lower levels of RNA.s.13

In order to measure an additional parameter of microsomal function, the effects of MAM acetate on drug-metabolizing enzymes and the ability of phenobarbital to induce these enzyme systems were examined. Ethylmorphine $N$-demethylase activity in microsomes was inhibited in a dose-dependent manner by the carcinogen (Fig. 4). However, the $O$-dealkylation of norcodeine was not markedly decreased until a dose of $20 \mathrm{mg} / \mathrm{kg}$ or larger was given. This differential inhibition of microsomal oxidases suggests that different rate-limiting events might be involved in these two systems or that the half-life of key components of the enzyme system might be longer in the case of norcodeine $O$ dealkylation. Alteration of other environmental conditions has been shown to affect these oxidase systems differently. ${ }^{9}$ In the experiments represented in Table 1 , ethylmorphine metabolism was inhibited $24 \mathrm{hr}$ after a $20 \mathrm{mg} / \mathrm{kg}$ dose of MAM acetate. By $72 \mathrm{hr}$ after carcinogen, ethylmorphine metabolism was still below control levels; however, the ability of the system to be induced by phenobarbital was not impaired at $24 \mathrm{hr}$ after MAM treatment since giving phenobarbital at this time produced the same incremental increase above noninduced levels as in the phenobarbital-treated controls. Enzyme activity in the animals that received both MAM acetate and phenobarbital did not reach the same absolute level as in the animals treated with phenobarbital and saline. The data presented in Table 2 indicates that the effects of DMN on microsomal oxidases were very similar to those of MAM acetate; there was a dose-dependent inhibition of ethylmorphine metabolism and a lesser inhibition of norcodeine oxidation.

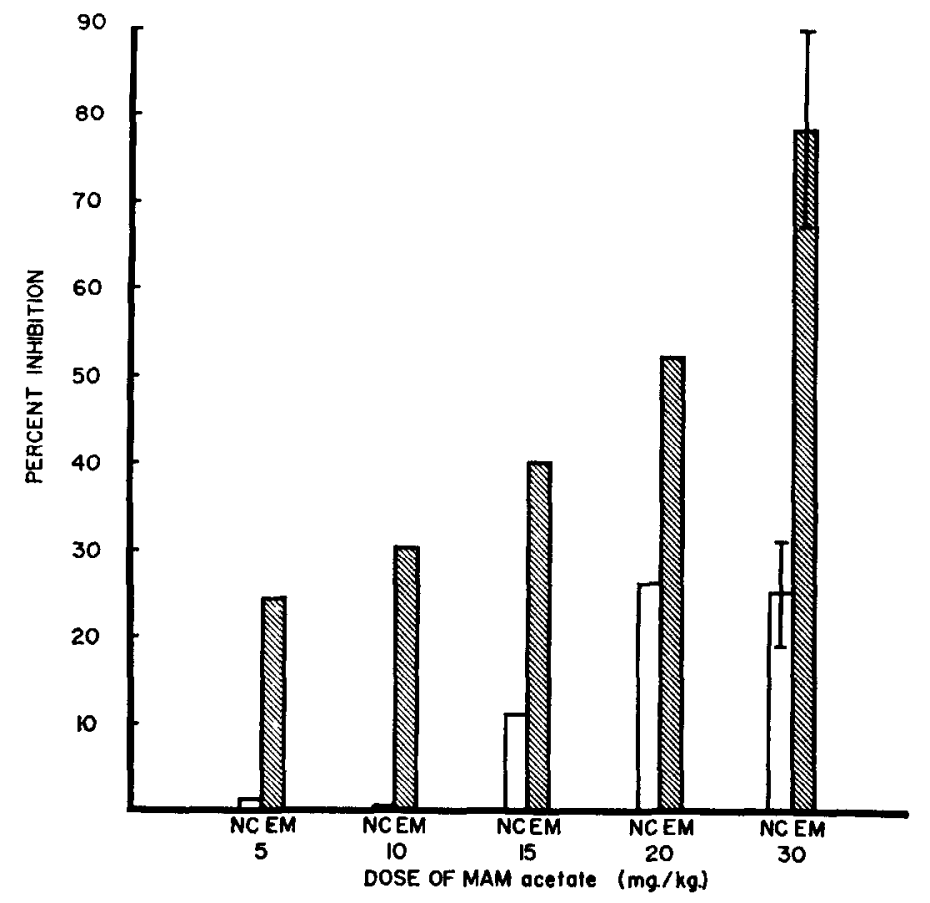

Fig. 4. Effects of various doses of MAM acetate on ethylmorphine (EM) and norcodeine (NC) metabolism in hepatic microsomes. Enzyme assays performed as described in the text. Each determination was based on duplicate samples from the pooled livers of two control or two treated animals, except for the $30 \mathrm{mg} / \mathrm{kg}$ dose which represents the mean \pm S.E. for six animals in each group. The specific activities (in m $\mu$ moles formaldehyde formed per milligram protein per minute) of the microsomal preparations from control animals (averaged from all experiments) were $4.26 \pm 0.54$ (S.E.) for EM and $2.63 \pm 0.31$ for NC. Animals were sacrificed $24 \mathrm{hr}$ after injection of MAM acetate or saline.

* G. S. Banks, P. B. Lundeen and R. W. Ruddon, unpublished observations. 
TABLE 1. INDUCTION OF ETHYLMORPHINE $N$-DEMETHYLASE ACTIVITY IN ANIMALS TREATED WTTH MAM ACETATR*

\begin{tabular}{cccccc}
\hline ¿Experiment & $\begin{array}{l}\text { Time after MAM } \\
\text { treatment (hr) }\end{array}$ & Control & MAM acetate & Phenobarbital & $\begin{array}{c}\text { Phenobarbital } \\
\text { and MAM acetate }\end{array}$ \\
\hline 1 & 24 & $2 \cdot 64$ & $1 \cdot 66(-37 \%)$ & & \\
& 48 & $3 \cdot 23$ & $2 \cdot 63(-19 \%)$ & $6.23(+93 \%)$ & $5 \cdot 43(+106 \%)$ \\
& 72 & $3 \cdot 55$ & $2 \cdot 31(-35 \%)$ & $7 \cdot 10(+100 \%)$ & $5 \cdot 03(+118 \%)$ \\
2 & 24 & $2 \cdot 97$ & $1 \cdot 10(-63 \%)$ & & \\
& 48 & $4 \cdot 67$ & $1 \cdot 50(-68 \%)$ & $10 \cdot 67(+128 \%)$ & $3.56(+137 \%)$ \\
\hline
\end{tabular}

* Animals were given MAM acetate $(20 \mathrm{mg} / \mathrm{kg}$ in Experiment 1 and $30 \mathrm{mg} / \mathrm{kg}$ in Experiment 2) at 0 time, then phenobarbital $(40 \mathrm{mg} / \mathrm{kg})$ at 24 or $48 \mathrm{hr}$ after MAM acetate, and sacrificed $24 \mathrm{hr}$ after phenobarbital was given. Controls were injected with $0.9 \% \mathrm{NaCl}$ at 0,24 and $48 \mathrm{hr}$. Ethylmorphine metabolism is expressed as m $\mu$ moles formaldehyde formed per milligram microsomal protein per minute. Values represent the mean of duplicate determinations from the pooled livers of two animals. Numbers in parentheses represent per cent change from control or in the case of the phenobarbitaltreated animals, per cent change from the "noninduced" level.

TABle 2. Drug-metabolizing enzyme activity $24 \mathrm{hr}$ after treatment WITH DIMETHYLNITROSAMINE*

\begin{tabular}{|c|c|c|c|c|c|}
\hline Experiment & Enzyme assay & Control & \multicolumn{3}{|c|}{ Dose of DMN $(\mathrm{mg} / \mathrm{kg})$} \\
\hline 1 & $\begin{array}{l}N \text {-dealkylation of } \\
\text { ethylmorphine } \\
O \text {-dealkylation of } \\
\text { norcodeine }\end{array}$ & $\begin{array}{l}4.05 \\
2 \cdot 42\end{array}$ & & $\begin{array}{c}15 \\
1.61 \\
(-60 \%) \\
1.78 \\
(-26 \%)\end{array}$ & $\begin{array}{c}30 \\
0.73 \\
(-82 \%) \\
1.39 \\
-43 \%)\end{array}$ \\
\hline 2 & $\begin{array}{c}N \text {-dealkylation of } \\
\text { ethylmorphine }\end{array}$ & $3 \cdot 16$ & $\begin{array}{c}7.5 \\
2.37 \\
(-25 \%)\end{array}$ & $\begin{array}{c}15 \\
2 \cdot 12 \\
(-33 \%\end{array}$ & $\begin{array}{c}20 \\
0.90 \\
(-72 \%)\end{array}$ \\
\hline
\end{tabular}

* Enzyme activity determined and expressed as stated in Table 1.

The evidence accumulated on inhibition of drug-metabolizing enzymes agrees with the pattern of general inhibition of protein synthesis. Twenty-four hr after treatment with $20 \mathrm{mg} / \mathrm{kg}$ of MAM acetate, drug-metabolizing enzymes were inhibited approximately 50 per cent. This inhibition could be due to the disruption of normal enzyme synthesis during the 24-hr period. Although only slight recovery of normal enzyme activity appears to occur in the $72 \mathrm{hr}$ following MAM acetate, the capacity to increase enzyme levels recovers by $24 \mathrm{hr}$ as evidenced by the ability of phenobarbital to induce microsomal enzyme activity. This suggests that the mechanism for enzyme synthesis is intact by that time.

It has been postulated that MAM and DMN have a common methylating intermediate formed in vivo. ${ }^{14,13}$ The methylation of mRNA could lead to polysome disaggregation and accelerated breakdown of mRNA, possibly accounting for the common pattern of protein synthesis inhibition. The similarities in the effects of DMN and MAM acetate on protein synthesis, polysome breakdown, and drug-metabolizing enzymes suggest a common mechanism of action of these agents. Whether or not these alterations are related to their carcinogenic potential remains to be determined.

Acknowledgements-This research has been supported by a grant from the National Institutes of Health (NIH-DE-02731).

Departments of Oral Biology and Pharmacology,

Peter B. Lundeen

The University of Michigan,

Ann Arbor, Mich. 48104, U.S.A.

Gerald S. BANKS

RAYMOND W. RUDDON 


\section{REFERENCES}

1. H. Matsumoto, T. Nagahama and H. O. Larson, Biochem. J. 95, 13c (1965).

2. A. Kobayashi and H. Matsumoto, Archs Biochem. Biophys. 110, 373 (1965).

3. I. Hirono, G. L. LAQuer and M. SPATz, J. natn. Cancer Inst. 40, 1003 (1968).

4. G. L. Laquer, E. G. MCDANIEL and H. Matsumoto, J. natn. Cancer Inst. 39, 355 (1967).

5. M. S. Zedeck, S. S. Sterngerg, R. W. Poynter and J. MCGowan, Cancer Res. 30, 801 (1970).

6. C. E. Ganote and A. S. Rosenthal, Lab. Invest. 19, 382 (1968).

7. R. C. Shank, Biochim. biophys. Acta 166, 578 (1968).

8. B. Fishman, R. Wurtman and H. MunRo, Proc. natn. Acad. Sci. U.S.A. 64, 677 (1969).

9. W. J. GeORGe and T. R. TEPHLY, Molec. Pharmac. 4, 502 (1968).

10. T. NASH, Biochem. J. 55, 416 (1953).

11. O. H. Lowry, N. J. Roserrough, A. L. FARR and R. J. Randall, J. biol. Chem. 193, 265 (1951).

12. G. BLoBel and V. PotTer, J. molec. Biol. 26, 279 (1969).

13. S. Villa-Trevino, Biochem. J. 105, 625 (1967).

14. H. Matsumoto and H. H. Higa, Biochem. J. 98, 20c (1966).

15. R. C. ShanK and P. N. MAGeE, Biochem. J. 105, 521 (1967).

Biochemical Pharmacology, Vol. 20, pp. 2527-2529. Pergamon Press, 1971. Printed in Great Britain

\section{"Titration" of acetylcholinesterase with soman}

(Received 28 December 1970; accepted 25 March 1971)

Previously described methods ${ }^{1}$ for estimation of the number of active sites in acetylcholinesterasepreparations (AChE, EC 3.1.1.7) seem to be rather troublesome and often expensive with respect to working time and the required amount of test material. The applicability of a more recently reported analytical procedure, described by Bender et al. ${ }^{2}$ is confined to preparations of relative high enzymatic activity. We should like to report on a considerably less expensive method in which only about $10^{-6}$ moles of acetylcholine are split per min per $\mathrm{mg}$ of enzyme; the active site concentration is in the range of $10^{-12} \mathrm{moles} / \mathrm{mg}$ enzyme, which is far below the requircd concentration for any direct (e.g. optical) detection method.*

The simple analytical procedure used in our laboratory is based on the measurement of the enzymic activity of AChE after partial inhibition by the phosphonylating agent soman [O-(1-methyl-2.2dimethylpropyl)-methyl-fluorophosphonate].

Due to the presence of two asymmetric centers (the P-atom and the C-1-atom of the 1-methyl-2.2dimethylpropyl-residue), soman consists of four stereoisomers. Keijer and Wolring ${ }^{4}$ found in 1969 that two of them (with the same configuration around the P-atom) react very fast with AChE (inhibition rate constants $k_{i}=2.8 \times 10^{7}$ and $1.2 \times 10^{8} \mathrm{M}^{-1} \mathrm{~min}^{-1}$ respectively), whereas the other two are relatively poor inhibitors $\left(k_{i} \leqslant 10^{4} \mathrm{M}^{-1} \min ^{-1}\right)$. Concerning the stereospecificity of chymotrypsin towards soman, Ooms and van Dijk ${ }^{5}$ reported a very similar observation: one pair of diastereomers (with identical configurations at the P-atoms) reacts fast $\left(k_{i}=2.0 \times 10^{3}\right.$ for both), the other slowly $\left(k_{t}<10^{3}\right)$. The method reported here is based on these findings.

\section{(a) Determination of concentration of the soman stock solution}

The solvent used for all stock solutions and experiments was distilled water containing 0.1 $\mathrm{M} \mathrm{NaCl}$ and $0.02 \mathrm{M} \mathrm{MgCl}_{2}$. In order to determine accurately the concentration of fast-reacting soman in stock solutions, the inhibition of chymotrypsin was measured.

* When this work was in progress, M. Nenner reported another method for the determination of active sites, based upon a special kinetical treatment of the bimolecular reaction between $\mathrm{AChE}$ and an organophosphorous inhibitor. ${ }^{3}$ 